\title{
Chemistry in Eriocaulaceae
}

Anne Lígia Dokkedal ${ }^{\mathrm{a}, *}$, Lourdes Campaner dos Santos ${ }^{\mathrm{b}}$, Paulo Takeo Sano ${ }^{\mathrm{c}}$, and Wagner Vilegas ${ }^{\mathrm{b}}$

a Departamento de Ciências Biológicas, Faculdade de Ciências, UNESP, C.P. 473, 17033-360 Bauru, SP, Brazil. Fax: (5514) 31036092. E-mail: dokkedal@fc.unesp.br

b Departamento de Química Orgânica, Instituto de Química de Araraquara, UNESP, C.P. $355,14801-970$ Araraquara, SP, Brazil

c Departamento de Botânica, Instituto de Biociências, Universidade de São Paulo, C.P. 11461, 05427-970 São Paulo, SP, Brazil

* Author for correspondence and reprint requests

Z. Naturforsch. 63c, 169-175 (2008); received August 13/November 7, 2007

Eriocaulaceae is a pantropical family that comprises about 1100 species distributed in 11 genera. The infrafamilial relationships are still unsatisfactorily resolved, because of the tiny flowers and generalized morphology, which makes the taxonomy very difficult. Flavonoid and naphthopyranone profiles have proved to be important in order to contribute to the alignment of genera into the family. We here present a survey of the chemical data of Eriocaulaceae with a discussion about their contribution to the taxonomy of Eriocaulaceae.

Key words: Eriocaulaceae, Flavonoids, Chemotaxonomy

\section{Introduction}

Eriocaulaceae is a pantropical, predominantly herbaceous monocotyledonous family, comprising around 1100 species in 11 genera (Giulietti et al., 2000; Sano, 2004). It is a common and diagnostic component of the herbaceous rocky outcrops vegetation of Brazil called "campos rupestres", that occurs above $900 \mathrm{~m}$ height. Plants of Eriocaulaceae live in sandy areas from swamps to drier soils and most of the species occurs mainly in Brazil (Giulietti and Hensold, 1991). Molecular and morphological studies characterized this family as a monophyletic group (Giulietti et al., 1995, 2000; Bremer, 2002) that is recognized by the following synapomorphies: very small, unisexual, white flowers, in dense capitulae, with only one ovule per locule, and spiraperturate pollen.

In spite of the monophyly of the group, infrafamilial relationships are still unsatisfactorily resolved (Giulietti and Hensold, 1991; Giulietti et al., 1995): Paepalanthus Mart., the largest genus, is polyphyletic (Giulietti et al., 2000).

Chemical investigation of some species has been shown to be useful to taxonomically characterize the delimitation of several taxa. The first report about chemistry of Eriocaulaceae was published on the species of Eriocaulon L. by Bate-Smith and Harborne (1969), who found the flavonols quercetagetin, gossypetin and patuletin in the metha- nolic extract of the leaves. Dokkedal and Salatino (1992) found several flavones (luteolin $C$-glycoside, luteolin 7- $O$-triglucoside, luteolin 7- $O$-diarabinoside, nepetin, nepetin 7-O-glucoside and nepetin 7-O-arabinoside) in the methanolic extract of the leaves of six Leiothrix species. From those data, the presence of different classes of flavonoids clearly distinguished Leiothrix Ruhland (= flavones) from Eriocaulon (= flavonols). Mayworm and Salatino (1993) investigated four species of Paepalanthus and found mainly 6-oxygenated flavonols (beyond flavones) in $P$. hilairei Koern. [= Actinocephalus bongardii (A - St. Hil.) Sano]. Flavone glycosides were found in 22 taxa of Syngonanthus (Ricci et al., 1996). This data suggested a close alignment between Leiothrix/Syngonanthus and distinguished this group from Eriocaulon/Paepalanthus. Besides flavonoids, Salatino et al. (1990) reported the contents of soluble phenolic compounds from the capitulae of eight species of Eriocaulaceae. Ho and Chen (2002) identified new flavan and hispidulin derivatives from the capitula of Eriocaulon buergerianum Koern.

Vilegas et al. (1990) investigated the chloroform extract of the capitula from Paepalanthus bromelioides Silveira and P. vellozioides Koern. and found a new isocumarin, named paepalantine. Paepalantine proved to be potent as antibiotic, cytotoxic and mutagenic (Varanda et al., 1997). Since that, 
our group has been extensively investigating the chemistry of Eriocaulaceae, which is in course up to now. Besides flavonol and naphthopyranone derivatives, Andrade et al. (1999) described two new acyl glycosylated flavonoids in five species of nowadays Actinocephalus (cited as Paepalanthus sect. Actinocephalus). The presence of these compounds showed the qualitative similarity between the species belonging to this taxon. These data were a very important contribution when Sano (2004) recognized Actinocephalus as a new genus of Eriocaulaceae. Vilegas et al. (1999a) reported the presence of quercetagetin 7-methyl ether glycosides from the leaves of Paepalanthus subg. Platycaulon Ruhland. In another work, Vilegas et al. (1999b) described new naphthopyranone glycosides from species of $P$. subg. Platycaulon. Coelho et al. (1999a, b) found luteolin $O$ - and $C$-glycosides in the capitula of Syngonanthus bisulcatus Ruhland. Besides eight known apigenin and luteolin $O$ - and $C$-glycosides, Santos et al. (2001) isolated several xanthones from Leiothrix species. Andrade et al. (2002) reported the presence of 6-methoxy flavonols in the capitula of Paepalanthus macropodus Ruhland, which also produced naphthopyranones and flavonol derivatives (Vilegas et al., 1999a). Santos et al. (2002) isolated four known flavonoids and the new 6-methoxyquercetin-3-O(6" $E$-feruloyl)- $\beta$-D-glucopyranoside from the aerial parts of $P$. polyanthus Bong. [= Actinocephalus polyanthus (Bong.) Sano].

In face of the great contribution of the chemical information on the taxonomy of Eriocaulaceae, the aim of this work is to increase the knowledge of the chemistry of the Eriocaulaceae in total as well as to support its classification.

\section{Results and Discussion}

We here present the substances isolated from leaves, scapes and/or capitulae of Eriocaulaceae species. Tables I-III present the distribution of substances found in Eriocaulaceae species. Isolated compounds are presented in Figs. 1-3.

Table I. Distribution of flavones in Eriocaulaceae.

\begin{tabular}{|c|c|c|c|c|c|c|c|c|c|c|c|c|c|c|c|c|}
\hline \multirow[t]{2}{*}{ Taxon } & \multicolumn{16}{|c|}{ Flavone } \\
\hline & 1 & 2 & 3 & 4 & 5 & 6 & 7 & 8 & 9 & 10 & 11 & 12 & 13 & 14 & 15 & 16 \\
\hline \multicolumn{17}{|l|}{ Paepalanthus } \\
\hline P. chlorocephalus & $\mathrm{xxx}$ & & & & & & $\mathrm{xxx}$ & & & & & & & & & \\
\hline$P$. argenteus var. argenteus & & $\mathrm{xxx}$ & $\mathrm{xxx}$ & & & & & & & & & & & & & \\
\hline \multicolumn{17}{|l|}{ P. sect. Actinocephalus } \\
\hline \multicolumn{17}{|l|}{ P. polyanthus } \\
\hline P. robustus & & & & & $\mathrm{x}$ & & & & & & & & & & & \\
\hline \multicolumn{17}{|l|}{ P. ramosus } \\
\hline \multicolumn{17}{|l|}{ P. denudatus } \\
\hline \multicolumn{17}{|l|}{ P. microphyllus } \\
\hline \multicolumn{17}{|l|}{ P. brachypus } \\
\hline \multicolumn{17}{|l|}{$P$. subsect. Aphorocaulon } \\
\hline \multicolumn{17}{|l|}{ P. macrocephalus } \\
\hline \multicolumn{17}{|l|}{$P$. sect. Diphyomene } \\
\hline \multicolumn{17}{|l|}{ P. speciosus } \\
\hline \multicolumn{17}{|l|}{ P. subg. Platycaulon } \\
\hline \multicolumn{17}{|l|}{ P. vellozioides } \\
\hline \multicolumn{17}{|l|}{ P. latipes } \\
\hline P. bromelioides & & $\mathrm{x}$ & & & & & & & & & & & & & & \\
\hline \multicolumn{17}{|l|}{ P. macropodus } \\
\hline P. planifolius & & & & & $\mathrm{XX}$ & $\mathrm{XX}$ & & & $\mathrm{XX}$ & & & $\mathrm{XX}$ & & & & \\
\hline \multicolumn{17}{|l|}{ Syngonanthus } \\
\hline S. bissulcatus & & & & $\mathrm{xx}$ & & $\mathrm{xxx}$ & $\mathrm{XXX}$ & $\mathrm{XXX}$ & & & & & & & & \\
\hline \multicolumn{17}{|l|}{ Leiothrix } \\
\hline L. curvifolia & & $\mathrm{XX}$ & & $\mathrm{XX}$ & & & & & & & & & & & & \\
\hline L. flavescens & & & & & & $\mathrm{xX}$ & $\mathrm{XX}$ & & & & & & & $\mathrm{xx}$ & & $\mathrm{XX}$ \\
\hline
\end{tabular}

Refer to Fig. 1 for the structures of the compounds. x, Trace amount; xx, intermediary content; xxx, majority. 
A. L. Dokkedal et al. · Chemistry in Eriocaulaceae

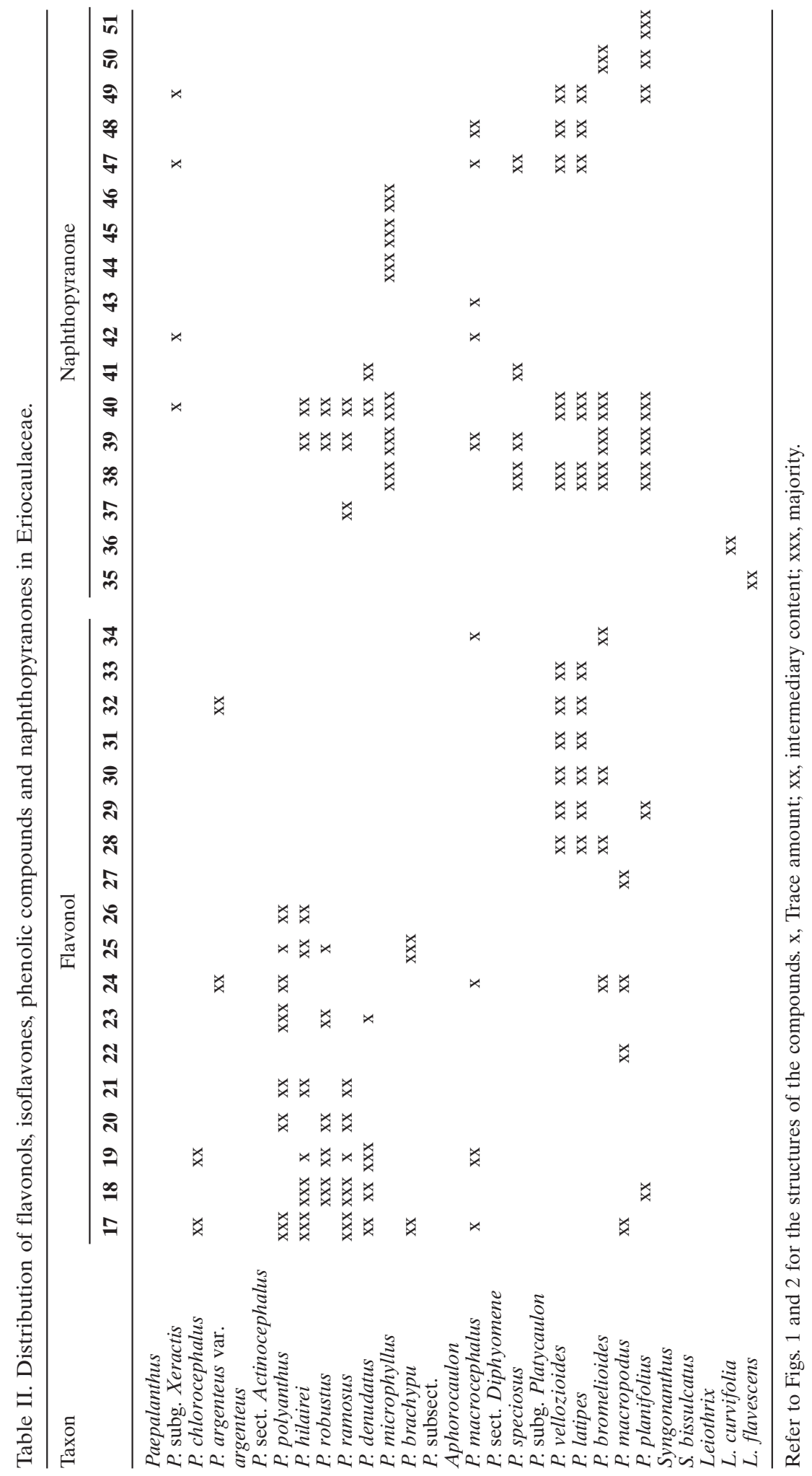


Table III. Distribution of xanthones in Eriocaulaceae.

\begin{tabular}{lccc}
\hline Taxon & \multicolumn{3}{c}{ Xanthone } \\
\cline { 2 - 4 } & $\mathbf{5 2}$ & $\mathbf{5 3}$ & $\mathbf{5 4}$ \\
\hline $\begin{array}{l}\text { Leiothrix } \\
\text { L. curvifolia }\end{array}$ & & $\mathrm{xxx}$ & $\mathrm{xxx}$ \\
L. flavescens & $\mathrm{xxx}$ & & \\
\hline
\end{tabular}

Refer to Fig. 3 for the structures of the compounds. $x$, Trace amount; $x x$, intermediary content; $x x x$, majority.<smiles>[R]c1ccc(-c2oc3c([Z])c([R])c([R])c(O)c3c(=O)c2[R])cc1[Y]</smiles>

1-35

\begin{tabular}{|c|c|c|c|c|c|c|}
\hline & $\mathrm{R}^{1}$ & $\mathrm{R}^{2}$ & $\mathrm{R}^{3}$ & $\mathrm{R}^{4}$ & $\mathrm{R}^{5}$ & $\mathrm{R}^{6}$ \\
\hline 1 & $\mathrm{H}$ & $\mathrm{OCH}_{3}$ & $\mathrm{OH}$ & $\mathrm{OH}$ & $\mathrm{OH}$ & $\mathrm{H}$ \\
\hline 2 & $\mathrm{H}$ & $\mathrm{OCH}_{3}$ & $\mathrm{OH}$ & $\mathrm{OCH}_{3}$ & $\mathrm{OH}$ & $\mathrm{H}$ \\
\hline 3 & $\mathrm{H}$ & $\mathrm{OCH}_{3}$ & O-glu & $\mathrm{OCH}_{3}$ & $\mathrm{OH}$ & $\mathrm{H}$ \\
\hline 4 & $\mathrm{H}$ & $\mathrm{H}$ & $\mathrm{OH}$ & $\mathrm{OH}$ & $\mathrm{OH}$ & \\
\hline 5 & $\mathrm{H}$ & $\mathrm{OH}$ & $\mathrm{OH}$ & $\mathrm{OH}$ & $\mathrm{OH}$ & $\mathrm{H}$ \\
\hline 6 & $\mathrm{H}$ & $\mathrm{OH}$ & O-glu & $\mathrm{OH}$ & $\mathrm{OH}$ & \\
\hline 7 & $\mathrm{H}$ & glu & $\mathrm{OH}$ & $\mathrm{OH}$ & $\mathrm{OH}$ & \\
\hline 8 & $\mathrm{H}$ & glu & O-glu & $\mathrm{OH}$ & $\mathrm{OH}$ & $\mathrm{H}$ \\
\hline 9 & $\mathrm{H}$ & $\mathrm{H}$ & $\mathrm{OH}$ & $\mathrm{H}$ & $\mathrm{OH}$ & \\
\hline 10 & $\mathrm{H}$ & $\mathrm{OH}$ & $\mathrm{OCH}_{3}$ & $\mathrm{H}$ & $\mathrm{OH}$ & $\mathrm{H}$ \\
\hline 11 & $\mathrm{H}$ & $\mathrm{OH}$ & O-glu & $\mathrm{H}$ & $\mathrm{OH}$ & \\
\hline 12 & $\mathrm{H}$ & glu & $\mathrm{OH}$ & $\mathrm{H}$ & $\mathrm{OH}$ & \\
\hline 13 & $\mathrm{H}$ & $\mathrm{OH}$ & O-glu & $\mathrm{OH}$ & O-glu & \\
\hline 14 & $\mathrm{H}$ & glu & $\mathrm{OCH}_{3}$ & $\mathrm{OH}$ & $\mathrm{OH}$ & \\
\hline 15 & $\mathrm{H}$ & $\mathrm{OH}$ & O-glu & $\mathrm{OH}$ & O-glu & \\
\hline 16 & $\mathrm{H}$ & $\mathrm{OH}$ & $\mathrm{OH}$ & $\mathrm{OH}$ & $\mathrm{OH}$ & $\mathrm{O}$ \\
\hline 17 & $\mathrm{OH}$ & $\mathrm{OCH}_{3}$ & $\mathrm{OH}$ & $\mathrm{H}$ & $\mathrm{OH}$ & \\
\hline 18 & O-glu & $\mathrm{OCH}_{3}$ & $\mathrm{OH}$ & $\mathrm{H}$ & $\mathrm{OH}$ & \\
\hline 19 & O-glu- $p$-coum & $\mathrm{OCH}_{3}$ & $\mathrm{OH}$ & $\mathrm{H}$ & $\mathrm{OH}$ & \\
\hline 20 & $\mathrm{OH}$ & $\mathrm{OH}$ & $\mathrm{OH}$ & $\mathrm{OH}$ & $\mathrm{OH}$ & \\
\hline 21 & $\mathrm{OH}$ & $\mathrm{OH}$ & O-glu & $\mathrm{OH}$ & $\mathrm{OH}$ & \\
\hline 22 & $\mathrm{OH}$ & $\mathrm{OH}$ & $\mathrm{OH}$ & $\mathrm{OH}$ & $\mathrm{OH}$ & $\mathrm{O}$ \\
\hline 23 & O-glu- $p$-coum & $\mathrm{OCH}_{3}$ & $\mathrm{OH}$ & $\mathrm{OH}$ & $\mathrm{OH}$ & \\
\hline 24 & $\mathrm{OH}$ & $\mathrm{OCH}_{3}$ & $\mathrm{OH}$ & $\mathrm{OH}$ & $\mathrm{OH}$ & \\
\hline 25 & O-glu & $\mathrm{OCH}_{3}$ & $\mathrm{OH}$ & $\mathrm{OH}$ & $\mathrm{OH}$ & \\
\hline 26 & O-rut & $\mathrm{OCH}_{3}$ & $\mathrm{OH}$ & $\mathrm{OH}$ & $\mathrm{OH}$ & \\
\hline 27 & O-glu-glu & $\mathrm{OCH}_{3}$ & $\mathrm{OH}$ & $\mathrm{OH}$ & $\mathrm{OH}$ & \\
\hline 28 & $\mathrm{OH}$ & $\mathrm{OH}$ & $\mathrm{OCH}_{3}$ & $\mathrm{OH}$ & $\mathrm{OH}$ & \\
\hline 29 & O-glu & $\mathrm{OH}$ & $\mathrm{OCH}_{3}$ & $\mathrm{OH}$ & $\mathrm{OH}$ & \\
\hline 30 & $\mathrm{OH}$ & $\mathrm{OH}$ & $\mathrm{OCH}_{3}$ & $\mathrm{OH}$ & O-glu & \\
\hline 31 & O-glu-glu & $\mathrm{OH}$ & $\mathrm{OCH}_{3}$ & $\mathrm{OH}$ & $\mathrm{OH}$ & \\
\hline 32 & O-glu-rham & $\mathrm{OH}$ & $\mathrm{OCH}_{3}$ & $\mathrm{OH}$ & $\mathrm{OH}$ & \\
\hline 33 & O-glu-glu-caff & $\mathrm{OH}$ & $\mathrm{OCH}_{3}$ & $\mathrm{OH}$ & $\mathrm{OH}$ & \\
\hline 34 & $\mathrm{OH}$ & $\mathrm{OCH}_{3}$ & O-glu & $\mathrm{OCH}_{3}$ & $\mathrm{OH}$ & \\
\hline & -glu-feru & $\mathrm{OCH}_{3}$ & $\mathrm{OH}$ & $\mathrm{OH}^{3}$ & $\mathrm{OH}$ & \\
\hline
\end{tabular}

Fig. 1. Flavonoids isolated from Eriocaulaceae species.
Table I demonstrates that flavone derivatives are frequent in Paepalanthus subg. Xeractis (Koern.) N. Hensold (P. argenteus var. argenteus Koern., P. chlorocephalus Silveira), as well as Syngonanthus and Leiothrix species. 6-Oxygenated flavonols are characteristic of Actinocephalus [A. polyanthus, A. robustus Silveira, A. denudatus (Koern.) Sano], while 7-methoxylated flavonols are more often found in Paepalanthus subg. Platycaulon Mart. (P. vellozioides, P. latipes Silveira, $P$. bromelioides, $P$. macropodus). Concerning naphthopyranones, Table II shows that these com-<smiles>COc1cc(O)c2c(=O)c(-c3ccc(OC)c(OC)c3O)coc2c1</smiles>

36<smiles>O=C(O)c1ccc(O)c(O)c1</smiles> 
pounds occur in large amounts in P. subg. Platycaulon, although they are also present in species belonging to $P$. sect. Actinocephalus, $P$. subsect. Aphorocaulon Ruhland and $P$. sect. Diphyomene Ruhland. Table III shows the occurrence of xanthone derivatives, which are exclusively from Leiothrix species.

A cladistic analysis based on 49 predominantly morphologic characters (Giulietti et al., 2000) suggested that Paepalanthus is polyphyletic and should be divided into smaller monophyletic genera. Eriocaulon is closely related to some groups of Paepalanthus, while Leiothrix and Syngonanthus emerge as sister groups. Based on biological, morphological, chemical and cytological characters, Sano (2004) proposed a new genus for Eriocaulaceae: Actinocephalus (Koern.) Sano, which in Ruhland's scheme (1903) was considered as a section in Paepalanthus subgenus Paepalocephalus and Körnicke (1863) considered as a subgenus of Paepalanthus. The other subgenera included in Paepalanthus (P. subg. Platycaulon, P. subg. Thelxinoё Mart., P. subg. Psilandra Mart.) display a considerably larger range of morphological variation at the species level, and therefore more detailed information about different aspects, such as morphology, anatomy, chemistry and cytology, is required. An exception is Paepalanthus subg. Xeractis, a group with 28 endemic species from the Serra do Espinhaço of Minas Gerais, Brazil (Hensold, 1988, 1998) and considered by Ruhland (1903) to be one of the few unquestionably natural infrageneric taxa. This group presents the flavone derivatives 1-3 (Fig. 1) as major constituents of $P$. chlorocephalus and P. argenteus var. argenteus. This result approaches $P$. subg. Xeractis to Leiothrix and Syngonanthus. These two genera are very close to each other and are chemically characterized by the presence of luteolin $O$ - and $C$-glycosides as main constituents. On the other hand, the presence of the xanthones 52-54 (Fig. 3) and the absence of naphthopyranones in Leiothrix species allow us to distinguish between Leiothrix and Paepalanthus, since naphthopyranones (but not xanthones) are common in many Paepalanthus species (Table II). The occurrence of xanthones in Leio-

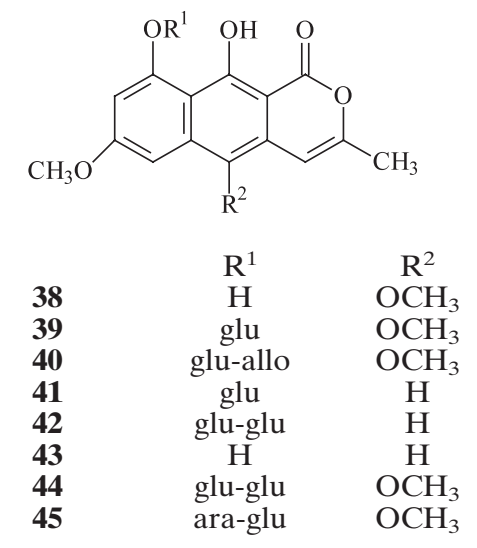<smiles></smiles>

50<smiles>[Y2]c1c2c(c(O)c3c(O)cc(OC)cc13)C(=O)OC(C)C2</smiles>

$$
\begin{array}{lcc} 
& \mathrm{R}^{1} & \mathrm{R}^{2} \\
\mathbf{4 7} & \text { glu } & \mathrm{H} \\
\mathbf{4 8} & \text { glu-glu } & \mathrm{H} \\
\mathbf{4 9} & \text { allo-glu } & \mathrm{H}
\end{array}
$$<smiles>COC1=Cc2cc3cc(OC)cc(OC)c3c(=O)c3c2C(O)=c2cc(C)oc(=O)c2=C(O)C3=C1</smiles>

51

Fig. 2. Naphthopyranones isolated from Eriocaulaceae species. 


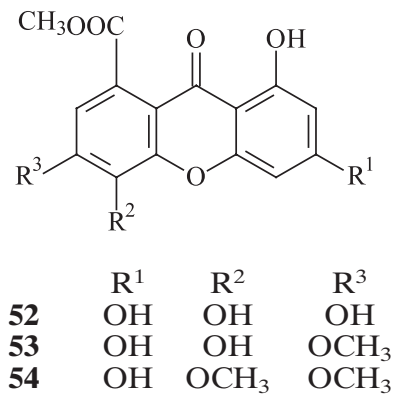

Fig. 3. Xanthones isolated from Eriocaulaceae species.

thrix contributes to distinguish this genus from Syngonanthus. Flavonoids also contribute to the chemical differentiation at the genus level, since Paepalanthus species produces 6- and/or 7-methoxyflavonol derivatives, whereas Leiothrix and Syngonanthus seem to produce mainly flavone derivatives (Santos et al., 2001, Dokkedal and Salatino, 1992; Ricci et al., 1996).

The chemical profile of $P$. macrocephalus Koern. (which belongs to $P$. subsect. Aphorocaulon) presents naphthopyranones (paepalantine derivatives and dihydronaphthopyranones 39, 42, 43, 47, 48, Fig. 2), in addition to other compounds, such as the acylated flavonols and flavonol glycosides 17, 19, 24, 34 (Fig. 1). The presence of naphthopyranones in $P$. subsect. Aphorocaulon is in agreement with the cladistic analysis (Giulietti et al., 2000), where this taxon forms a sister group with Actinocephalus (which has a similar chemical profile).

Chemical data corroborate the phylogenetic hypothesis that Paepalanthus is polyphyletic and must be divided into a number of more natural groups. The chemical composition has proved to be an important taxonomic character, since the chemical profiles are quite distinct in the different taxa, although not necessarily exclusive. The occurrence of 6-methoxylated flavonoids as well as glycosylation at C-3 seems to be a major trend in Paepalanthus. The presence of naphthopyranones, mainly paepalantine derivatives, is characteristic of $P$. subg. Platycaulon, together with minor amounts of dihydronaphthopyranones and flavonol derivatives. The proximity of $P$. subg. Platy- caulon to P. subsect. Aphorocaulon, P. serie Dimeri Ruhland, $P$. sect. Diphyomene Ruhland and Actinocephalus is also supported by the similarity between their chemical profiles, which include flavonol and naphthopyranone derivatives in all of them (see Table II). This proximity indicates probably a common evolutionary history, as shown by the cladistic analysis of Giulietti et al. (2000). Actinocephalus, on the other hand, can be distinguished from the other taxa by the presence of acylated flavonol glycosides as well as glycosylated derivatives of paepalantine. These chemical characters reinforce Actinocephalus as a distinct genus separated from Paepalanthus as proposed by Sano (2004). In P. subsect. Aphorocaulon, major constituents are monoglycosylated paepalantine, desmethoxypaepalantine and dihydronaphthopyranones, and in P. sect. Diphyomene these are mono- and diglycosylated paepalantine and glycosylated dihydronaphthopyranone. Paepalanthus subg. Xeractis is characterized by the presence of flavone derivatives and minor amounts of paepalantine, desmethoxypaepalantine and dihydronaphthopyranone derivatives. Therefore, the presence of these compounds in $P$. subg. Xeractis gives support for a close relationship between $P$. subg. Xeractis and Leiothrix/Syngonanthus, as demonstrated by the cladistic treatment (Giulietti et al., 2000). Furthermore, this profile corroborates the proposition of Giulietti et al. (2000), who stated that P. subg. Xeractis is very distinct from Paepalanthus. The presence of flavones instead of flavonols in both $P$. subg. Xeractis and Leiothrix/Syngonanthus group is in agreement with the fact that flavones often appear to replace flavonols in the most advanced groups (Salatino et al., 1990). Finally, xanthones can be useful chemical markers to distinguish between Leiothrix and Syngonanthus (Santos et al., 2001).

\section{Acknowledgements}

We acknowledge FAPESP and FUNDUNESP for financial funding and a fellowship to L. C. S. We thank CNPq for a grant to W. V. and P. T. S. We are also in debt to Dr. Ana Maria Giulietti and Marcelo Trovó for critical review and suggestions. 
Andrade F. D. P., Santos L. C., Dokkedal A. L., and Vilegas W. (1999), Acyl glycosylated flavonoids from Paepalanthus species. Phytochemistry 51, 411-415.

Andrade F. D. P., Rastrelli L., Pizza C., Sano P. T., and Vilegas W. (2002), Flavonol glycosides and a naphthopyranone glycoside from Paepalanthus macropodus (Eriocaulaceae). Biochem. Syst. Ecol. 30, 257-277.

Bate-Smith E. C. and Harborne J. B. (1969), Quercetagetin and patuletin in Eriocaulon. Phytochemistry 8, $1035-1037$.

Bremer K. (2002), Gondwanan evolution of the grass alliance of families (Poales). Evolution 56, 1374-1387.

Coelho R. G., Vilegas W., and Parra L. R. (1999a), Flavonóides C-glicosilados de S. bisulcatus. Proceedings of the 22th Annual Meeting of the Brazilian Chemical Society, Gramado, RS. Edited by Brazilian Chemical Society, Gramado, RS, Brazil, p. 17.

Coelho R. G., Vilegas W., Parra L. R., and Sano P. T. (1999b), Estudo químico dos escapos de S. bisulcatus. Proceedings of the II Reunião da Sociedade Latinoamericana de Fitoquímica. Edited by Sociedad Latinoamericana de Fitoquímica, Valparaiso, Chile, p. 71.

Dokkedal A. L. and Salatino A. (1992), Flavonoids of Brazilian Leiothrix Ruhl. (Eriocaulaceae). Biochem. Syst. Ecol. 20, 31-32.

Giulietti A. M. and Hensold N. (1991), Synonymization of the genera Comanthera and Carptotepala with Syngonanthus (Eriocaulaceae). Ann. Miss. Bot. Gard. 78, $460-464$.

Giulietti A. M., Amaral M. C., and Bittrich V. (1995), Phylogenetic analysis of inter- and infrageneric relationships of Leiothrix Ruhl. (Eriocaulaceae). Kew Bull. 50, 55-71.

Giulietti A. M., Scatena V. L., Sano P. T., Parra L. R., Queiroz L. P., Harley R. M., Menezes N. L., Yseppon A. M. B., Salatino A., Salatino M. L., Vilegas W., Santos L. C., Ricci C. V., Bonfim M. C. P., and Miranda E. B. (2000), Multidisciplinary studies on neotropical Eriocaulaceae. In: Monocots: Systematics and Evolution (Wilson K. L. and Morrison D. A., eds.). CSIRO, Melbourne, pp. 580-588.

Hensold N. (1988), Morphology and systematics of Paepalanthus subgenus Xeractis (Eriocaulaceae). Syst. Bot. Monogr. 23, 1-150.

Hensold N. (1998), Flora da Serra do Cipó, Minas Gerais: Paepalanthus subg. Xeractis (Eriocaulaceae). Bol. Bot. Univ. São Paulo 17, 207-218.
Ho J. C. and Chen C. M. (2002), Flavonoids from the aquatic plant Eriocaulon buergerianum. Phytochemistry 61, 405-408.

Körnicke F. (1863), Eriocaulaceae. In: Flora Brasiliensis, Vol. 3, part 1 (Martius C. F. P. and Eichler A. W., eds.). Typographia Regia, Munich, pp. 273-307.

Mayworm M. A. S. and Salatino A. (1993), Flavonóides de quatro espécies de Paepalanthus Ruhl. (Eriocaulaceae). Acta Bot. Bras. 7, 129-134.

Ricci C. V., Patrício M. C., Salatino M. L. F., Salatino A., and Giulietti A. M. (1996), Flavonoids of Syngonanthus Ruhl. (Eriocaulaceae): taxonomic implications. Biochem. Syst. Ecol. 24, 577-583.

Ruhland W. (1903), Eriocaulaceae. In: Das Pflanzenreich, Vol. 4 (Engler A., ed.). Wilhelm Engelmann, Leipzig, pp. 1-294.

Salatino A., Salatino M. L. F., Santos D. Y. A. C., and Patrício M. B. C. (1990), Distribution and evolution of secondary metabolites in Eriocaulaceae, Lythraceae and Velloziaceae from campos rupestres. Gen. Mol. Biol. 23, 931-940.

Sano P. T. (2004), Actinocephalus (Koern.) Sano (Paepalanthus sect. Actinocephalus), a new genus of Eriocaulaceae, and other taxonomic and nomenclatural changes involving Paepalanthus Mart. Taxon 53, 99107.

Santos L. C., Piacente S., De Ricardis F., Eletto A. M., Pizza C., and Vilegas W. (2001), Xantones and flavonoids from Leiothrix curvifolia and Leiothrix flavescens. Phytochemistry 56, 853-856.

Santos L. C., Piacente S., Pizza C., Toro R., Sano P. T., and Vilegas W. (2002), 6-Methoxyquercetin-3-O-(6"$E$-feruloyl)- $\beta$-D-glucopyranoside. Biochem. Syst. Ecol. 30, $451-456$.

Varanda E. A., Raddi M. S., Dias F. L. P., Araújo M. C. S., Gibran S. C. A., Takahashi C. S., and Vilegas W. (1997), Evaluation of the genotoxic potential of the isocoumarin paepalantine in vivo and in vitro mammalian systems. Teratog. Carcinog. Mutagen. 17, $85-95$

Vilegas W., Roque N. F., Salatino A., Giesbrecht A. M., and Davino S. (1990), Isocoumarin from Paepalanthus bromelioides. Phytochemistry 29, 2299-2301.

Vilegas W., Dokkedal A. L., Rastrelli L., Piacente S., and Pizza C. (1999a), Naphthopyranone glycosides from Paepalanthus bromelioides and P. latipes. J. Nat. Prod. 62, 746-749.

Vilegas W., Nehme C. J., Dokkedal A. L., Piacente S., and Rastrelli L. (1999b), Flavonoid glycoside from the leaves of Paepalanthus bromelioides and P. latipes. Phytochemistry 51, 403-409. 